\title{
Special issue: recognizing the lifetime scientific contributions of Athina Markou
}

\author{
John F. Cryan ${ }^{1} \cdot$ Harriet de Wit ${ }^{2}$
}

Published online: 18 April 2017

(C) Springer-Verlag Berlin Heidelberg 2017

Athina Markou, who passed away far too young in May 2016, dedicated her entire scientific life to psychopharmacology. This Special Issue has been assembled to commemorate the immense impact that her work has had on the field and to highlight her legacy. Indeed, with more than 200 articles in peer-reviewed journals including Nature, Nature Neuroscience and PNAS not to mention as recounted by Trevor Robbins in his generous obituary in this special issue (Robbins 2017), the 34 articles in Psychopharmacology, Athina has played a major role in the development of the field over the past three decades. In addition, Athina was a stalwart member of the European Behavioural Pharmacology Society, this journal's society partner.

The special issue is bookended on one side by a personal and comprehensive review by George Koob, Athina's PhD mentor, of Athina's most renowned work-her contribution to understanding motivational dysregulation in addiction using experimental models (Koob 2017). Indeed, among her most important findings was the observation that nicotine withdrawal induces anhedonic effects in rats similar to other major drugs of abuse (Epping-Jordan et al. 1998). This enabled her to have a model for assessing novel strategies for developing anti-addictive agents including mGlu and $\mathrm{GABA}_{\mathrm{B}}$ receptor ligands (Cryan et al. 2003; Kenny and Markou 2004). In this regard, Winsky and Brady (2017) describe how Athina created collaborative networks to develop novel treatments for

John F. Cryan

J.Cryan@ucc.ie

1 Department of Anatomy and Neuroscience, University College Cork, Cork, Ireland

2 Department of Psychiatry and Behavioral Neuroscience, University of Chicago, Chicago, IL, USA nicotine abuse and mental disorders. Moreover, reviewing the field and Athina's contribution Anton Bespalov and colleagues focus on mGlu1 receptor as a drug target for treatment of substance use disorder (Dravolina et al. 2017) whereas Jane Acri details the journey that mGlu2 ligands have come on as therapeutic targets for substance abuse (Acri et al. 2016). On the other hand, Christian Chiamulera highlights the state of the art for mGlu5 ligands as treatments for nicotine dependence (Chiamulera et al. 2016). With regard to $\mathrm{GABA}_{\mathrm{B}}$ receptors, McDonald and colleagues present new research on a novel $\mathrm{GABA}_{\mathrm{B}}$ receptor positive allosteric modulator for nicotine dependence (Li et al. 2017) whereas Jacobson and colleagues highlight interactions between $\mathrm{GABA}_{\mathrm{B}}$ receptors and 5-HT system (Jacobson et al. 2017). The special issue is also focused on other novel targets for drug dependence; among those highlighted are neuropeptides (Bruijnzeel et al. 2017), Toll-like receptors (Crews et al. 2017), 5- $\mathrm{HT}_{2 \mathrm{C}}$ receptors (Palacios et al. 2017), opioid receptors (Norman and D’Souza 2017), glycine site ligands (Yohn et al. 2017) and alpha7 receptors (Higa et al. 2017).

Athina Markou's influence has spread beyond that of substance use disorders often focusing on other diseases with shared neurobiological mechanisms. Moreover, her focus on the principles underlying the validity of animal models of psychiatric disease has been very important, guiding their appropriate use when translating basic research findings into efforts to develop new therapeutics (Geyer and Markou 1995; Cryan et al. 2002; Barnes et al. 2014; Pergadia et al. 2014). In the special issue, this is exemplified by the papers from Baldo on feeding mechanisms (Selleck and Baldo 2017), O'Dell on diabetes (Pipkin et al. 2017), Belin on impulsivity (Rotge et al. 2017) and Dalley and colleagues on perseveration (Zhukovsky et al. 2017). The overlap between stress and reward pathways has been one of the key themes emerging from Athina's research (Der-Avakian et al 2014) and there is a fitting review on this 
relationship (Slattery and Cryan 2017) as well as articles on the failure ofCRF1 receptor antagonists in drug development efforts to date (Spierling and Zorrilla 2017). Liu and colleagues present new data on the role of isolation stress on impulsivity-related behaviours (Liu et al. 2017) whereas Semanova and colleagues focus on impact of another early-life stress protocol interacting with adolescent exposure to ethanol (Boutros et al. 2017). DerAvakian focuses on adult social defeat stress and its functional consequences on behaviour and neurochemistry (Der-Avakian et al. 2017).

Athina always had her eye focus on clinical translation of her rodent findings and it is thus fitting that there are two human psychopharmacology papers focused on overlapping neurobiology of both hallucinogens and schizophrenia with drug dependence (Alexander et al. 2017; Liechti et al. 2017).

We would like to thank all of the authors for their rapid and very enthusiastic response to the call for articles and hope that the Special Issue offers a glimpse into the legacy that Dr. Markou has had on the field and will continue through her trainees, collaborators and friends. We would also like to extend our sympathies to Professor Mark Geyer and to all Athina's family and friends at this difficult time.

\section{References}

Acri JB, Cross AJ, Skolnick P (2016) From bench to bedside: mGluR2 positive allosteric modulators as medications to treat substance use disorders. Psychopharmacology (Berl). doi:10.1007/s00213-0164501-9

Alexander PD, Gicas KM, Willi TS, Kim CN, Boyeva V, Procyshyn RM, Smith GN, Thornton AE, Panenka WJ, Jones AA, Vila-Rodriguez F, Lang DJ, William MacEwan G, Honer WG, Barr AM (2017) A comparison of psychotic symptoms in subjects with methamphetamine versus cocaine dependence. Psychopharmacology (Berl). doi: 10.1007/s00213-017-4551-7

Barnes SA, Der-Avakian A, Markou A (2014) Anhedonia, avolition, and anticipatory deficits: assessments in animals with relevance to the negative symptoms of schizophrenia. Eur Neuropsychopharmacol 24(5):744-758

Boutros N, Der-Avakian A, Markou A, Semenova S (2017) Effects of early life stress and adolescent ethanol exposure on adult cognitive performance in the 5-choice serial reaction time task in Wistar male rats. Psychopharmacology (Berl). doi:10.1007/s00213-017-4555-3

Bruijnzeel AW (2017) Neuropeptide systems and new treatments for nicotine addiction. Psychopharmacology (Berl). doi:10.1007/ s00213-016-4513-5

Chiamulera C, Marzo CM, Balfour DJ (2016) Metabotropic glutamate receptor 5 as a potential target for smoking cessation. Psychopharmacology (Berl). doi:10.1007/s00213-016-4487-3

Crews FT, Walter TJ, Coleman LG Jr, Vetreno RP (2017) Toll-like receptor signaling and stages of addiction. Psychopharmacology (Berl). doi:10.1007/s00213-017-4560-6

Cryan JF, Markou A, Lucki I (2002) Assessing antidepressant activity in rodents: recent developments and future needs. Trends Pharmacol Sci 23(5):238-245

Cryan JF, Gasparini F, van Heeke G, Markou A (2003) Non-nicotinic neuropharmacological strategies for nicotine dependence: beyond bupropion. Drug Discov Today 8(22):1025-1034
Der-Avakian A, Mazei-Robison MS, Kesby JP, Nestler EJ, Markou A (2014) Enduring deficits in brain reward function after chronic social defeat in rats: susceptibility, resilience, and antidepressant response. Biol Psychiatry 76(7):542-549

Der-Avakian A, D'Souza MS, Potter DN, Chartoff EH, Carlezon WA Jr, Pizzagalli DA, Markou A (2017) Social defeat disrupts reward learning and potentiates striatal nociceptin/orphanin FQ mRNA in rats. Psychopharmacology (Berl). doi:10.1007/s00213-017-4584-y

Dravolina OA, Zvartau E, Danysz W, Bespalov AY (2017) mGlu1 receptor as a drug target for treatment of substance use disorders: time to gather stones together? Psychopharmacology (Berl). doi:10.1007/ s00213-017-4581-1

Epping-Jordan MP, Watkins SS, Koob GF, Markou A (1998) Dramatic decreases in brain reward function during nicotine withdrawal. Nature 393(6680):76-79

Geyer MA, Markou A (1995) Animal models of psychiatric disorders. In: Bloom FE, Kupfer DJ (eds) Psychopharmacology: the fourth generation of progress. Raven Press, New York, pp 787-798

Higa KK, Grim A, Kamenski ME, van Enkhuizen J, Zhou X, Li K, Naviaux JC, Wang L, Naviaux RK, Geyer MA, Markou A, Young JW (2017) Nicotine withdrawal-induced inattention is absent in alpha7 nAChR knockout mice. Psychopharmacology (Berl). doi:10. 1007/s00213-017-4572-2

Jacobson LH, Hoyer D, Fehlmann D, Bettler B, Kaupmann K, Cryan JF (2017) Blunted 5-HT(1A) receptor-mediated responses and antidepressant-like behavior in mice lacking the GABA(B1a) but not GABA(B1b) subunit isoforms. Psychopharmacology (Berl). doi: 10.1007/s00213-016-4521-5

Kenny PJ, Markou A (2004) The ups and downs of addiction: role of metabotropic glutamate receptors. Trends Pharmacol Sci 25(5):265-272

Koob GF (2017) Antireward, compulsivity, and addiction: seminal contributions of Dr. Athina Markou to motivational dysregulation in addiction. Psychopharmacology (Berl). doi:10.1007/s00213-0164484-6

Li X, Sturchler E, Kaczanowska K, Cameron M, Finn MG, Griffin P, McDonald P, Markou A (2017) KK-92A, a novel GABA(B) receptor positive allosteric modulator, attenuates nicotine self-administration and cue-induced nicotine seeking in rats. Psychopharmacology (Berl)

Liechti ME, Dolder PC, Schmid Y (2017) Alterations of consciousness and mystical-type experiences after acute LSD in humans. Psychopharmacology (Berl). doi:10.1007/s00213-016-4453-0

Liu YP, Wilkinson LS, Robbins TW (2017) 'Waiting impulsivity' in isolation-reared and socially-reared rats: effects of amphetamine. Psychopharmacology (Berl). doi:10.1007/s00213-017-4579-8

Markou A, Cryan JF (2012) Stress, anxiety and depression: toward new treatment strategies. Neuropharmacology 62(1):1-2

Norman H, D'Souza MS (2017) Endogenous opioid system: a promising target for future smoking cessation medications. Psychopharmacology (Berl). doi:10.1007/s00213-017-4582-0

Palacios JM, Pazos A, Hoyer D (2017) A short history of the 5-HT(2C) receptor: from the choroid plexus to depression, obesity and addiction treatment. Psychopharmacology (Berl). doi:10.1007/s00213017-4545-5

Pergadia ML, Der-Avakian A, D'Souza MS, Madden PA, Heath AC, Shiffman S, Markou A, Pizzagalli DA (2014) Association between nicotine withdrawal and reward responsiveness in humans and rats. JAMA Psychiatry 71(11):1238-1245

Pipkin JA, Cruz B, Flores RJ, Hinojosa CA, Carcoba LM, Ibarra M, Francis W, Nazarian A, O'Dell LE (2017) Both nicotine reward and withdrawal are enhanced in a rodent model of diabetes. Psychopharmacology (Berl). doi:10.1007/s00213-017-4592-y

Robbins TW (2017) In Memory of Athina Markou (1961-2016): Obituary. Psychopharmacology (Berl). doi:10.1007/s00213-016$4524-2$ 
Rotge JY, Cocker PJ, Daniel ML, Belin-Rauscent A, Everitt BJ, Belin D (2017) Bidirectional regulation over the development and expression of loss of control over cocaine intake by the anterior insula. Psychopharmacology (Berl). doi:10.1007/s00213-017-4593-x

Selleck RA, Baldo BA (2017) Feeding-modulatory effects of mu-opioids in the medial prefrontal cortex: a review of recent findings and comparison to opioid actions in the nucleus accumbens. Psychopharmacology (Berl). doi:10.1007/s00213-016-4522-4

Slattery DA, Cryan JF (2017) Modelling depression in animals: at the interface of reward and stress pathways. Psychopharmacology (Berl). doi:10.1007/s00213-017-4552-6

Slattery DA, Markou A, Froestl W, Cryan JF (2005) The GABAB receptorpositive modulator GS39783 and the GABAB receptor agonist baclofen attenuate the reward-facilitating effects of cocaine: intracranial self-stimulation studies in the rat. Neuropsychopharmacology 30(11): 2065-2072
Spierling SR, Zorrilla EP (2017) Don't stress about CRF: assessing the translational failures of CRF(1)antagonists. Psychopharmacology (Berl). doi:10.1007/s00213-017-4556-2

Winsky L, Brady LS (2016) Athina Markou's contributions to treatment development for mental illnesses: a perspective. Psychopharmacology (Berl). doi:10.1007/s00213-016-4485-5

Yohn SE, Alberati D, Correa M, Salamone JD (2017) Assessment of a glycine uptake inhibitor in animal models of effortrelated choice behavior: implications for motivational dysfunctions. Psychopharmacology (Berl). doi:10.1007/s00213-016-4523-3

Zhukovsky P, Alsiö J, Jupp B, Xia J, Guiliano C, Jenner L, Griffiths J, Riley E, Ali S, Roberts AC, Robbins TW, Dalley JW (2017) Perseveration in a spatial-discrimination serial reversal learning task is differentially affected by MAO-A and MAO-B inhibition and associated with reduced anxiety and peripheral serotonin levels. Psychopharmacology (Berl). doi:10.1007/s00213-017-4569-x 